\title{
A rapid and reproducible method for isolating genomic DNA from a few crop plants suitable for polymerase chain reaction-based genotyping
}

\author{
Vikash Kumar, Pawan Kumar, Tirthartha Chattopadhyay* \\ Bhagalpur- 813210 (Bihar), INDIA \\ *Corresponding author. E-mail: tirthartha@gmail.com \\ Received: September 22, 2016; Revised received: January 24, 2017; Accepted: May 15, 2017
}

Department of Plant Breeding and Genetics, Bihar Agricultural College, Bihar Agricultural University, Sabour,

\begin{abstract}
As most of the molecular markers in crop molecular breeding programmes are successful based on polymerase chain reaction (PCR), the isolated genomic DNA must be suitable for the same. Though PCR is a robust method and in most of the cases requires only a minute amount of genomic DNA as template, removal of potential PCR-inhibitory factors is quite important. The present work reports the optimization of a rapid genomic DNA isolation method, suitable for PCR-based genotyping of plants. As very minute amount of the genomic DNA isolated in this rapid method was found to be sufficient for PCR, a researcher is capable to go for several hundred independent PCR from single isolation. The method was validated in 4 different crops (wheat, tomato, brinjal and cauliflower) using different PCR-based molecular markers. In case of wheat, genomic DNA isolated in this method was found to be suitable PCR using the specific marker for the detection of the Lr34 gene. For tomato, genomic DNA isolated in this method was successfully used with the molecular markers for the detection of resistance alleles for yellow leaf curl disease and root knot disease. In case of brinjal, the isolated genomic DNA was found to be suitable for simple sequence repeat (SSR) marker assay. In a similar way, genomic DNA isolated in this method from cauliflower leaves was observed to be suitable for amplifying a gene of $\sim 1.5 \mathrm{~kb}$ length. Thus, this method will be quite helpful to expedite marker assisted selection of plants in plant molecular breeding programmes.
\end{abstract}

Keywords: Genomic DNA, Molecular markers, polymerase Chain Reaction, Rapid method, SDS-potassium acetate method

\section{INTRODUCTION}

Isolation of good quality genomic DNA from crop plants is a prerequisite for several downstream applications in plant molecular biological research. In case of plant molecular breeding, based on marker assisted selection of plants in a segregating population, genomic DNA isolation from a large number of plants often becomes a challenging task. Though automation of genomic DNA isolation is the choice for laboratories equipped with the concerned instruments, several laboratories, lacking these instruments are dependent on manual isolation of genomic DNA from plant tissues. The standard method mostly adopted for DNA isolation from plant tissues (Doyle and Doyle, 1987) is not only lengthy, but also labour- intensive, as it requires crushing of plant tissues in mortar and pestle in presence of liquid nitrogen. Naturally, several attempts have been made to optimize a rapid method for plant DNA extraction (Edwards et al., 1991; Cheung et al., 1993; Steiner et al., 1995; Aljanabi and Martinez 1997; Xin et al., 2003). One of these procedures (Xin et al., 2003) even allows isolation of genomic DNA without tissue grinding. However, all these procedures require $\sim 30 \mathrm{~min}$ to prepare the genomic DNA. In a recent past, a method developed for potato (Hosaka 2004) and validated for different crops like rice, wheat, lentil and Indian mustard (Singh et al., 2015) has been reported. Unfortunately, we failed to obtain similar result in case of wheat by adopting this method in our laboratory. Hence, attempts were made towards minor modifications of the method, for achieving more reproducibility. Through validation in different crops (i.e., wheat, tomato, brinjal and cauliflower) using different polymerase chain reaction (PCR)-based markers, the present study reports a rapid (taking $\sim 15 \mathrm{~min}$ ) and reproducible method for genomic DNA isolation from plant leaf tissues.

\section{MATERIALS AND METHODS}

Plant materials and PCR-based markers: List of plant materials and different PCR-based markers used in the present study is presented in Table 1.

Genomic DNA isolation: The optimization of the rapid DNA isolation method was done using wheat leaves (cultivar: PBW343) as per the methods presented in Fig. 1. Around $100 \mathrm{mg}$ of leaf tissue was collected in a micro-centrifuge tube and crushed in $400 \mu \mathrm{l}$ of buffer [100 mM Tris-Cl, $50 \mathrm{mM}$ EDTA, $500 \mathrm{mM} \mathrm{NaCl}, 0.1$ $\%(\mathrm{w} / \mathrm{v})$ SDS and $0.1 \%(\mathrm{v} / \mathrm{v}) \beta$-mercaptoethanol] us- 
Table 1. Genotypes and the markers used in the present study.

\begin{tabular}{|c|c|c|c|c|}
\hline Crop & Genotype(s) & Marker(s) & Marker type & Reference \\
\hline Wheat & PBW 343 & $\operatorname{csLV34}$ & $\begin{array}{l}\text { Co-dominant STS marker for the detec- } \\
\text { tion of } L r 34 \text { gene }\end{array}$ & (Lagudah et al., 2006) \\
\hline Tomato & $\begin{array}{l}\text { Arka Vikash, Pusa } \\
\text { Rohini, Pusa } 120 \\
\text { and Arka Aloke }\end{array}$ & $\begin{array}{l}P 6-25 \\
(P 6-25-F 2 / P 6-25 \\
-R 5)\end{array}$ & $\begin{array}{l}\text { Co-dominant SCAR marker for detec- } \\
\text { tion of } T y-3 / T y-3 a / T y-3 b \text { alleles for to- } \\
\text { mato yellow leaf curl disease resistance }\end{array}$ & (Jensen et al., 2007) \\
\hline \multirow{3}{*}{ Brinjal } & \multirow{3}{*}{$\begin{array}{l}\text { Solanum aethiopi- } \\
\text { cum, Swarna Mani, } \\
\text { Rajendra Baigan-2 } \\
\text { and Muktakeshi }\end{array}$} & $P M i F 3 / P M i R 3$ & $\begin{array}{l}\text { Co-dominant SCAR marker for detec- } \\
\text { tion of } \mathrm{Mi} 1-2 \text { allele for root knot disease } \\
\text { resistance } \\
\text { EST-derived SSR marker }\end{array}$ & $\begin{array}{l}\text { (ElMehrach et al., } \\
2005 \text {; Arens et al., } \\
\text { 2010) } \\
\text { (Tümbilen etal 2011) }\end{array}$ \\
\hline & & $\triangle M D S K$ OT & ES I-derived SSK marker & \\
\hline & & SmSSR 21 & EST-derived SSR marker & \\
\hline Cauliflower & $\begin{array}{l}\text { Pusa Kartik Shan- } \\
\text { kar and Pusa Sarad }\end{array}$ & $\begin{array}{l}\text { BoR2R3MybFor } \\
\text { BoR2R3MybRev }\end{array}$ & $\begin{array}{l}\text { Gene-specific primers for amplifying the } \\
p r \text { gene }\end{array}$ & $\begin{array}{l}\text { Primers designed in this } \\
\text { present study on the } \\
\text { basis of sequence avail- } \\
\text { able at public database } \\
\text { NCBI (Accession No. } \\
\text { GU219987) }\end{array}$ \\
\hline
\end{tabular}

ing a micro-pestle. After crushing and a brief centrifugation, the supernatant was distributed equally $(100 \mu \mathrm{l}$, each) in 4 new micro-centrifuge tubes. For method A, sample in one tube was processed as described previously (Singh et al., 2015). For method B and method $\mathrm{C}, 32 \mu \mathrm{l}$ of $5 \mathrm{M}$ potassium acetate was added and the samples were mixed briefly. Following a brief centrifugation, the supernatants were collected in separate tubes and either equal volume of isopropanol (method B) or equal volume of chloroform: isoamyl alcohol [24:1 (v/v), method C] was added. For method B, DNA was precipitated using a brief centrifugation, washed in $70 \%$ ethanol, dried at $55{ }^{\circ} \mathrm{C}$ for $5 \mathrm{~min}$ and dissolved in $200 \mu \mathrm{l}$ of molecular biology grade water. For method $\mathrm{C}$, the sample was again mixed briefly and after a brief centrifugation, the upper layer was collected in a new microcentrifuge tube. DNA present in this phase was precipitated and processed similarly, as in case of method B. In case of method D, 5 M potassium acetate was not added and sample was extracted with equal volume of chloroform:isoamyl alcohol [24:1 $(\mathrm{v} / \mathrm{v})]$. DNA was recovered, precipitated and processed similarly, as in case of method $\mathrm{C}$. In all the cases, $10 \mu \mathrm{l}$ of isolated genomic DNA was used as template for a $25 \mu \mathrm{l} \mathrm{PCR}$. The PCR mixture contained template DNA $(10 \mu \mathrm{l}), 2.5 \mu \mathrm{l}$ of $10 \mathrm{X}$ PCR buffer with $\mathrm{MgCl}_{2}$ (Xcelris), $0.1 \mathrm{mM}$ of dNTP mix (Xcelris), $0.4 \mu \mathrm{M}$ of forward and reverse primers and $0.5 \mathrm{U}$ of Taq DNA polymerase (Xcelris). PCR amplification was performed using the thermal profile consisting of an initial denaturation at $94{ }^{\circ} \mathrm{C}$ for $4 \mathrm{~min}$ followed by 35 cycles of $30 \mathrm{~s}$ at $94{ }^{\circ} \mathrm{C}, 40 \mathrm{~s}$ at appropriate annealing temperature, $30 \mathrm{~s}$ at $72{ }^{\circ} \mathrm{C}\left(90 \mathrm{~s}\right.$ at $72^{\circ}$ $\mathrm{C}$ in case of cauliflower), and ended with final extension at $72{ }^{\circ} \mathrm{C}$ for $10 \mathrm{~min}$ followed by hold at $4{ }^{\circ} \mathrm{C}$.

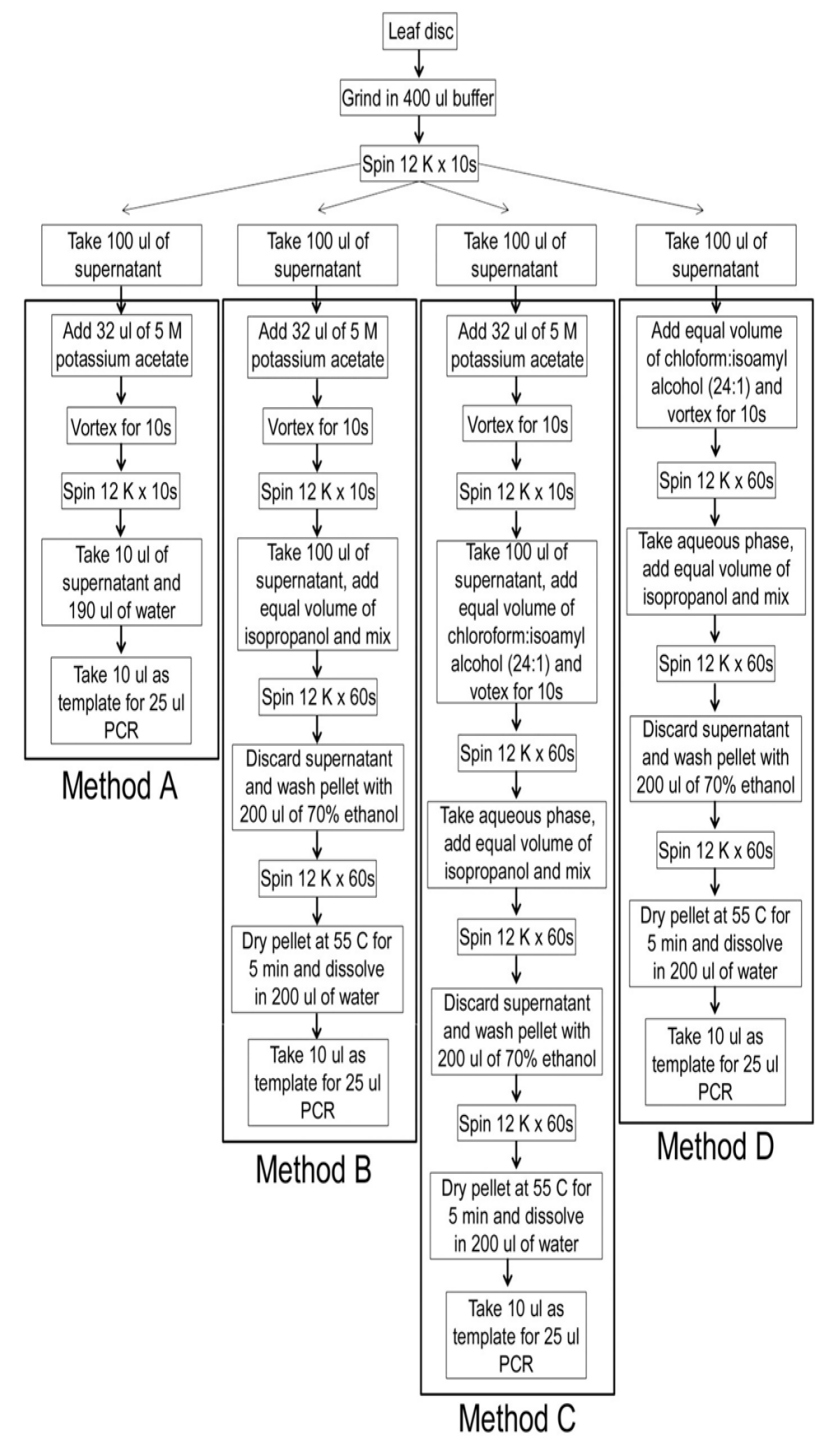

Fig. 1. Schematic diagram outlining the different methods used for optimizing rapid DNA isolation method. 

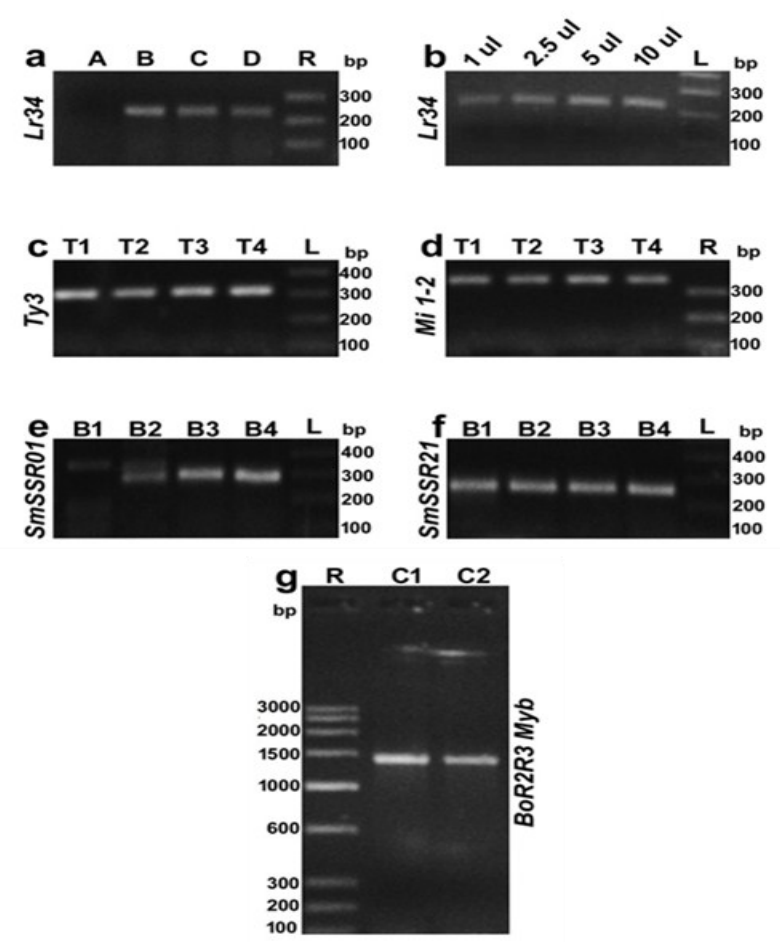

Fig. 2. Agarose gels showing amplicons for validation of the rapid DNA isolation method in different crop plants using different PCR-based markers. aAmplicons obtained in case of csLV34 marker in wheat (cultivar PBW 343) using genomic DNA isolated in 4 different methods $(A, B, C$ and $D) . b$ Amplicons obtained in case of csLV34 marker in wheat (cultivar PBW 343) using different amount of genomic DNA isolated in method $B$ as template. cAmplicons obtained in case ofTy 3 marker in 4 tomato genotypes using genomic DNA isolated in method B. $d$ Amplicons obtained in case of Mi 1-2 marker in 4 tomato genotypes using genomic DNA isolated in method B. e Amplicons obtained in case of SmSSR01 marker in 4 brinjal genotypes using genomic DNA isolated in method B. $f$ Amplicons obtained in case of SmSSR 1 marker in 4 brinjal genotypes using genomic DNA isolated in method B. $g$ Amplicons obtained by gene-specific primers for the pr gene (1432 bp) in 2 cauliflower genotypes using genomic DNA isolated in method B. T1 Arka Vikash, T2 Pusa Rohini, T3 Pusa 120, T4 Arka Aloke, B1 Solanum aethiopicum, B2 Swarna Mani, B3 Rajendra Baigan-2, B4 Muktakeshi, C1 Pusa Kartik Shankar, C2 Pusa Sarad, R Low range DNA ruler (Bangalore Genei), L 100 bp DNA ladder (Bangalore Genei).

\section{RESULTS AND DISCUSSION}

In order to optimize a rapid DNA isolation method, the method developed for potato (Hosaka, 2004) and validated for different crops like rice, wheat, lentil and Indian mustard (Singh et al., 2015) was used as the base protocol and three modifications, based on this method was attempted (Fig. 1). The base method (method A, Fig. 1) is a modified version of the SDSpotassium acetate method, reported earlier (Dellaporta et al., 1993), which uses the strong anionic detergent SDS to help in release of genomic DNA after breaking down the cellular membrane and denaturation of DNA binding proteins like histones. The SDS present in solution then forms insoluble complex with potassium acetate and is removed easily through centrifugation. However, owing to the strong denaturing capacity of SDS, even a minute contamination of residual SDS and/or other PCR inhibitory factors in the preparation may cause the failure of PCR. Hence, we tried to further optimize this method through incorporation of some additional steps (Method B, C and D, Fig. 1). Afterwards, wheat DNA isolated in the 4 different methods (A, B, C and D) was used as template to set PCR. Interestingly, agarose gel electrophoresis revealed the absence of band in case of the sample where genomic DNA isolated through method A was used, whereas sharp band was present in all the other 3 samples, where genomic DNA was isolated through method B/C/D (Fig. 2a). As the Lr34 is a co-dominant sequence tag site (STS) marker in nature, absence of band clearly indicates a failure in PCR, which might be due to the residual SDS and/or other PCR inhibitory factors possibly present in the sample prepared through method A. Furthermore, It was found that even $1 \mu \mathrm{l}$ of isolated DNA in method B is sufficient to generate sharp band in $25 \mu \mathrm{l} \mathrm{PCR}$ volume (Fig. 2b). Hence, the amount of DNA isolated in method B is sufficient for $\sim 200$ individual PCR, whereas, processing of the total volume of crushed material (i.e., $400 \mu \mathrm{l}$ ) should yield sufficient amount of genomic DNA for $\sim 800$ individual PCR.

In order to validate this method B of DNA isolation, genomic DNA was isolated from the leaves of different cultivars of tomato, brinjal and cauliflower. In case of tomato, genomic DNA isolated from 4 different cultivars was subjected to PCR using co-dominant sequence characterized amplified region (SCAR) marker P6-25 for identifying the $T y 3 / T y 3 a / T y 3 b$ allele conferring resistance to the tomato yellow leaf curl disease. In all the cases, the ty3 susceptible allelespecific $\sim 320$ bp band was observed (Fig. 2c). In case of PCR using the $P M i F 3 / P M i R 3$ primer pair to identify the presence of $M i$ 1-2 allele conferring resistance to root knot disease, the $\sim 350$ bp susceptible allelespecific band was observed (Fig. 2d). In a similar manner, PCR of genomic DNA isolated from 1 wild type and 3 cultivars of brinjal using expressed sequence tag (EST)-derived simple sequence repeat (SSR) markers (SmSSR01 and SmSSR21) revealed the presence of sharp bands after gel electrophoresis of the amplicons (Fig. 2e, 2f). Furthermore, genomic DNA isolated in this method from 2 cauliflower cultivars was used to amplify the entire $p r$ gene encoding an R2R3 Myb transcription factor (Chiu et al., 2010). In case of both the cultivars, the $1432 \mathrm{bp}$ desired amplicon was visible as sharp band after agarose gel electrophoresis (Fig. $2 \mathrm{~g}$ ). This result indicated the suitability of this method 
of DNA isolation not only for routine PCR application but also for preparative PCR intended towards gene cloning.

\section{Conclusion}

Genomic DNA isolation from crop plants is generally a time-consuming and labour-intensive process. Presently, most of the molecular markers are based on PCR, which is a robust technique and requires a very minute amount of genomic DNA as template. However, quality of the isolated DNA is a major factor that determines the efficiency of PCR-based genotyping. The present study has optimized a simple, rapid and reproducible method for genomic DNA isolation from different crop plants. A minute amount of isolated genomic DNA was found to be sufficient for PCR, enabling the researcher to use the isolated DNA for several hundred independent PCRs. The isolated DNA remains stable for several months, when stored at $-20{ }^{\circ} \mathrm{C}$ (data not shown). Though this method is relatively lengthy (takes $\sim 15 \mathrm{~min}$ ) than the method validated in recent past (Singh et al., 2015), the present method seems to have better reproducibility (i.e., $100 \%$ PCR efficiency), as compared to the previously described method ( $95 \%$ PCR efficiency). Thus, this method will be helpful to expedite marker assisted selection of plants through PCR-based genotyping in molecular breeding programmes.

\section{ACKNOWLEDGEMENTS}

The authors thank Dr. Nitish De for providing the csLV34 marker. Financial support from Department of Science and Technology, Govt. of India, in terms of project grant (SB/YS/LS-74/2013) is acknowledged. Vikash Kumar and Pawan Kumar thank DST and BAU respectively, for providing fellowship. The authors also thank Dr. P. K. Singh (Chairman) and Dr. Mankesh Kumar, Department of Plant Breeding and Genetics, Bihar Agricultural University, Sabour for their helps and supports. The authors have no conflict of interest. This article bears BAU COMMUNICATION NO. 100/2016.

\section{REFERENCES}

Aljanabi, S. M. and Martinez, I. (1997). Universal and rapid salt-extraction of high quality genomic DNA for PCRbased techniques. Nucleic. Acids. Res., 25:4692-4693

Arens, P., Mansilla, C., Deinum, D., Cavellini, L., Moretti, A., Rolland, S., van der Schoot, H., Calvache, D., Ponz, F., Collonnier, C., Mathis, R., Smilde, D., Caranta, C. and Vosman, B. (2010). Development and evaluation of robust molecular markers linked to disease resistance in tomato for distinctness, uniformity and stability testing. Theor. Appl. Genet., 120: 655-664

Cheung, W. Y., Hubert, N. and Landry, B. S. (1993). A simple and rapid DNA microextraction method for plant, animal, and insect suitable for RAPD and other PCR analyses. Genome Res,. 3: 69-70

Chiu, L-W., Zhou, X., Burke, S., Wu, X., Prior, R. L. and Li, L. (2010). The purple cauliflower arises from activation of a MYB transcription factor. Plant Physiol., 154: 1470 $-1480$

Dellaporta, S. L., Wood, J. and Hicks, J. B. (1983). A plant DNA minipreparation: version II. Plant. Mol. Biol. Rep., 1: 19-21

Doyle, J. J. and Doyle, J. L. (1987). A rapid DNA isolation procedure for small quantities of fresh leaf tissue. Phytochem. Bull. 19: 11-15

Edwards, K., Johnstone, C. and Thompson, C. (1991). A simple and rapid method for the preparation of plant genomic DNA for PCR analysis. Nucleic. Acids. Res., 19: 1349

ElMehrach, K., Mejía, L., Gharsallah-Couchane, S., Salus, M. S., Martin, C. T., Hatimi, A., Vidavski, F., Williamson, V. and Maxwell, D. P. (2005). PCR-based methods for tagging the $\mathrm{Mi}-1$ locus for resistance to root-knot nematode in begomovirus-resistant tomato germplasm. Acta Hort., 695: 263-270

Hosaka, K. (2004). An easy, rapid, and inexpensive DNA extraction method, "One-minute DNA extraction," for PCR in potato. Amer. J. Potato. Res., 81: 17-19

Jensen, K. S., van Betteray, B., Smeets, J., Ji, Y., Scott, J. W., Mejía, L., Havey, M. J. and Maxwell, D. P. (2007). http://www.plantpath.wisc.edu/Geminivirus Resistant Tomatoes/Markers/MAS-Protocols/P6-25-locus.pdf.

Lagudah, E. S.., McFadden, H., Singh, R. P., Huerta-Espino, J. and Bariana, H. S. (2006). Molecular genetic characterization of the $\operatorname{Lr} 34$ /Yrl 18 slow rusting resistance gene region in wheat. Theor. Appl. Genet., 114:21-30

Singh, V. K., Singh, V. K., Ellur, R. K., Gopala Krishnan, S. and Singh, A. K. (2015). Validation of rapid DNA extraction protocol and their effectiveness in marker assisted selection in crop plants. Indian J Genet., 75:110 113

Steiner, J. J., Poklemba, C. J., Fjellstrom, R. G. and Elliott, L. F. (1995). A rapid one-tube genomic DNA extraction process for PCR and RAPD analyses. Nucleic. Acids. Res., 23: 2569-2570

Tümbilen, Y., Frary, A., Daunay, M. C. and Doğanlar, S. (2011). Application of EST-SSRs to examine genetic diversity in eggplant and its close relatives. Turk. J. Biol., 35:125-136

Xin, Z., Velten, J.P., Oliver, M.J. and Burke, J.J. (2003). High-throughput DNA extraction method suitable for PCR. Bio Techniques, 34: 820-826 